\title{
Contested terrain of extractive development in the American West: using a regional political ecology framework to understand scalar governance, biocentric values, and anthropocentric values
}

\author{
Jeffrey Jenkins ${ }^{1}$ \\ University of California, Santa Cruz, USA
}

\begin{abstract}
The American West has seen a resurgence of capital investment in extractive mineral development on federal lands, emanating from the recent global financial crisis. For these extractive projects, as in energy development more broadly, struggles over knowledge persist in the pre-operational phases of exploratory access and environmental review when political-legal rights and scientific facts are coordinated, codified, and contested. Contested knowledge about extractive mineral development beyond the $100^{\text {th }}$ meridian, once more narrowly limited to proximate environmental impacts like water quality, now more broadly encompasses themes of scalar governance, landscape-level conservation, and local resource access. The case studies covered here demonstrate that a regional scale approach to political ecology provides utility as a heuristic to conceptually frame the concepts of governance, resource access, and ecological degradation between larger processes of economic restructuring and more localized micro politics. A case study approach is used to empirically support the claim that region provides a meso-scale of analysis in terms of: scalar resource control - state versus federal (southeast Utah); biocentric values - preserving nature for nature's sake (southern Arizona); and anthropocentric values - newly touted, but grounded in age-old utilitarianism (northeast Wyoming).
\end{abstract}

Keywords: extractive industries, American West, federal lands, biocentric, anthropocentric

\section{Résumé}

L'Ouest américain a vu une résurgence d'investissements en capitaux dans l'extraction de minéraux sur les territoires fédéraux, émanant de la récente crise financière. Pour ces projets d'extraction, comme pour le développement de l'énergie de façon plus globale, les conflits liés à l'acquisition de savoir persistent dans les phases pré-opérationnelles d'accès exploratoire et d'analyse environnementale quand les droits politicojuridiques et faits scientifiques sont coordonnés, codifiés et contestés. Les informations contestées concernant le développement d'extraction de minéraux au delà du $100^{\text {ème }}$ méridien, auparavant plus limitées à des impacts environnementaux directs comme la qualité de l'eau, englobent maintenant des thèmes plus larges comme la gouvernance multi-scalaire, la conservation et la gestion à l'échelle du paysage et l'accès aux ressources. Les études de cas présentées ici démontrent qu'une approche à l'échelle régionale de l'écologie politique apporte une utilité heuristique pour formuler conceptuellement les principes de gouvernance, d'accès aux ressources, et de dégradation écologique entre les processus plus larges de restructuration économique, et ceux plus localisés de micro-politique. La méthode de l'étude de cas est utilisée pour soutenir empiriquement l'affirmation soutenant que la région permet une analyse à échelle méso en termes de: contrôle de ressources scalaires - Etat v. Etat fédéral (Utah du sud-est); valeurs biocentriques - préserver la nature pour elle-même (Arizona du Sud); et des valeurs anthropocentriques - récemment mises en avant mais ancrées dans un utilitarisme séculaire (Wyoming du nord-est).

Mots-clés: industries extractives, Ouest américain, territoires fédéraux, biocentrique, anthropocentrique

\footnotetext{
1 Jeffrey Jenkins, Ph.D. submitted, Department of Environmental Studies, University of California, Santa Cruz, Interdisciplinary Sciences Building, 1156 High St., Santa Cruz, CA. 95064, USA. Email: jsjenkin "at" ucsc.edu. The author would like to express gratitude to the following funders for their financial support that allowed for writing time and field-based research: The Benjamin and Ruth Hammett Fellowship for Climate Change and Water Issues; Santa CruzWatsonville Inquiry-Based Learning in Environmental Sciences (NSF GK-12 DGE-0947923); and the University of California-Santa Cruz Department of Environmental Studies. This is the eighth article in Innisfree McKinnon and Colleen Hiner (eds.) 2016. "(Re)considering regional political ecology?", Special Section of the Journal of Political Ecology 23: 115-203.
} 


\section{Resumen}

El oeste americano ha visto un resurgimiento de la inversión de capital en el desarrollo minero extractivo en tierras federales, que emana de la reciente crisis financiera global. Para estos proyectos extractivos, como con el desarrollo de la energía en términos más generales, las luchas por el conocimiento persisten en las fases previas a la operación de acceso de exploración y revisión ambiental cuando se coordinan los derechos político-legales y los hechos científicos, codificaron y impugnados. La contestación, sobre el desarrollo minero extractiva más allá del meridiano 100, limita una vez más estrechamente a los impactos ambientales inmediatos, como la calidad del agua, ahora abarca más ampliamente temas de gobernabilidad escalar, la conservación a nivel de paisaje, y acceso a los recursos locales. Los estudios de casos cubiertos aquí demuestran que un enfoque regional a escala de la ecología política proporciona utilidad como una heurística para enmarcar conceptualmente los conceptos de gobernabilidad, acceso a los recursos y la degradación ecológica entre los procesos más amplios de la reestructuración económica y la política micro más localizadas. Un estudio de caso se utiliza para apoyar empíricamente la afirmación de que la región ofrece una meso-escala de análisis en términos de: control de recursos de escalar - estado frente federal (sureste de Utah); los valores biocéntricos - preservación de la naturaleza por el bien de la naturaleza (sur de Arizona); y los valores antropocéntricos - recién promocionado, pero a tierra en la vejez utilitarismo (noreste de Wyoming).

Palabras clave: industrias extractivas, oeste americano, tierras federales, biocéntricos, antropocéntricas

\section{Natural resource conflict and eco-transformation in the American West}

Scale is used as a heuristic in political ecology literature, and human-environment geography more broadly, to help frame interactions of power and agency, socioecological processes, and stakeholder networks, particularly as it relates to scalar politics of the state's control over access to resources and the environment (Neumann 2009b). The regional scale of analysis is a core conceptual tool in political ecology because it heuristically sets the discipline apart as a field (or subfield) based on what is to be explained. The use of a 'middle ground' allows one to adopt a type of scalar gaze in response to ecological events where one is disabused of a priori assumptions, theories, or biases about the importance of some type of political factor as an explanation of environmental change (Vayda and Walters 1999). The concept of a region allows the inquisitor to enter the issue in need of explanation at any given level, so long as it is relative to both larger and smaller scales of causation with degradation as both the start to and end of the story. The region is particularly pertinent in issues of natural resource or land use conflict. As Neumann (2009a) points out, reflecting on Blaikie and Brookfield's (1987) work on regional political ecology, regions take on the ontological position of 'things' transformed by external forces (local and global), and this is especially the case of commodityproducing regions. They are as discursively produced as they are produced materially through state regulations, global markets, and local livelihoods that reproduce social and ecological relationships (Jenkins 2011).

In first-world political ecology, themes related to rural land use conflict and access to resources include community-based resource management, the question of competing scientific and lay knowledge systems, and intersecting processes of social and environmental marginalization (McCarthy 2002, Schroeder, Martin and Albert 2006). In terms of knowledge and power, local claims stand in contrast to the political, legal, economic, and historical interests of the state and corporation when they converge or diverge around how nature works (ontological constructs of biophysical reality and ecological interrelationships), and who controls the environment (political-legal claims to natural resources informed by competing epistemologies and sets of values) (Benson 2012, Robbins 2006). And in the case of subterranean extraction, or what Bebbington and Bury (2013) refer to as a "political ecology of the subsoil", political scale, claims to ownership, and how knowledge is constructed about proximate and ultimate causes of environmental degradation are further embedded in the social terrain.

These themes are exemplified in the American West where the economic structure of rural communities has important ties to social structure and demographics; livelihoods are linked to the region's competing land uses, either associated with natural resource extraction or amenity-migrant economies (Robbins et al. 2009). The boom and bust of the minerals extraction industry influences the expansion and 
contraction of community social structure and local economic activity, which in turn is driven by a combination of regulations, land ownership, commodity prices on the global market, technological innovation and the geophysical setting (Aschmann 1970, Gulliford 1989, Hostetter 2011). 'Ecotransformation' describes the economic and environmental transformations jointly taking place in rural areas, specifically the American West; global economic restructuring has shifted the region's extractive resources base, including timber, mining, agriculture, and livestock to economies that rely on the amenity-value of the landscape in the form of exurban housing, recreation tourism, and service-based industries (Duane 1998). One caveat to this simplified explanation is that this economic shift is no longer bifurcated neatly between the 'old' extraction and the 'new' amenity. Rather, the 'next' West is an uneven landscape where both old and new persist as archipelagos in a sea of one another, depending on natural resource bases, proximity to urban areas, shifting credit (both agriculture and housing-based), global energy markets as extractive incentives, neoliberal conservation projects, and the degree of collaborative planning or regulatory regimes (Duane 2012). This being said, there has been a strong resurgence in the mining and energy sector throughout the region since the financial crisis of 2007-2008, which restructured economic conditions for investment in extractive projects. The resurgence in extractive economies has been most felt in the inter-mountain West. For instance, between 2007 and 2013 Wyoming's overall gross domestic product increased by 12.6 percent while gross domestic product contributions from the mining sector increased by 25.7 percent, resulting in mining making up 34.3 percent of the 2013 state economic output. Mining made up between 5 and 10 percent of the 2013 gross domestic product for Colorado, Nevada, New Mexico, and Montana, and this lower figure, though still a significant economic sector, may be due to more diversified economies emanating from larger urban population centers (BEA 2014).

The resurgence in extractive Old West industries, namely mining projects, has led to a wave of social contestation no longer limited to the proximate environmental legacy of extraction (e.g. diminished water quality) nor the simple bifurcation of Old and New West values. Rather, subterranean struggles across the economically diversified Next West are dominated by themes of scalar governance and control, landscapelevel conservation efforts, and how surface resources should be allocated to serve local economies. These processes unfold at the regional scale, leading us to ask what is the utility of a regional scale approach in political ecology? And, how can a regional scale approach facilitate a better understanding of the continually changing natural resource politics of the American West? The case studies below outline themes of extractive mineral development struggles in the context of national political economic restructuring and the micro politics of local case studies to empirically support the claim that the utility of a regional political ecology approach, indeed the very concept of region, is as a conceptual heuristic that allows one to situate the politics of state control, degradation, and local resource access related to ecology at a "meso-scale" (Walker and Fortmann 2003), within wider or denser contexts (Vayda 1983). That is, the concept of a region is only as fruitful as the themes that bind it to local socioeconomic or ecological effects of larger political economic affects, and to some degree of iteration vice-versa: local micropolitics feedback to influence larger political economic processes (e.g. the recent moratorium on coal leases by the Obama administration has national and global political economic implications, and this 'Keep it in the Ground' movement originated with local activist groups). Region in political ecology can be used a conceptual tool at the borderlands of micro political and global or national political economic processes to help one arrive at common themes, rather than as an a priori concept, scale, or gazetted feature in and of itself.

I will discuss the significance of scalar governance, biocentric values, and anthropocentric values in order to support to the claim that the utility of regional approach to political ecology lies in its ability to serve as a heuristic or conceptual scale at the confluence of wider economic restructuring and narrower micro political processes. I will first discuss how the politics of land use degradation have unfolded in Utah between local grazing permittees and the federal government over the past decades. Today the majority of energy and mining in Utah takes place on federal lands through leases administered by the Bureau of Land Management and while anti-statist efforts to redistribute federal lands to state and market interests ride on the coattails of 'wise use' land management, they are nevertheless more closely tied to a desire for greater extractive royalties. The argument of the extractive dependent state is that there is demand for greater oil and gas production, but I provide data that shows each year many hectares of private leases on federal lands are left undeveloped - due to national and international market competition - showing this phenomenon is grounded in a desire to grab 
more land and to invoke more flexible environmental regulations, rather than based on pure market demand. Next, I turn to the southeastern corner of Arizona, sometimes referred to as the nation's Copper Belt for its rich mining legacy, and by others referred to as the Sky Islands province for its biodiversity among geoecological archipelagoes. It is here that there is a proposal for what could be the nation's largest copper mine is proposed on U.S. Forest Service lands, but efforts from state and federal agencies to protect endangered megafauna and their critical habitat continue to delay the mine's development. I provide an overview of the regulatory evolution of this micro political landscape to show how environmental regulations related to mineral development and endangered species have come together to produce an unlikely outcome: blocking the development of a mine, not for the known risk it poses to water quality for human populations but rather because the proposed location sits within the habitat corridor of a non-human, migratory species, the jaguar. Lastly, I detail how opposition to rare earth mining development in the Black Hills of Wyoming has come from an unlikely source, the local land users who rely on the working landscape, rather than the more traditional urban environmental groups advocating for preservation. Residents of the surrounding municipalities, many of them who work in the region's coal mining and energy industries, support the economic boost a proposed mine might bring, however it is those who utilize the U.S. Forest Service lands for their own livelihoods that see the potential degradation caused by a hard rock mine as a risk to their local economy, an economy with multiple uses like grazing and off-highway vehicles that themselves contribute to degradation. I use the case of a watershed that was over-grazed, restored through an inter-agency collaboration, and now threatened by diminished water quality from mining to discuss competing notions of degradation.

These case studies were chosen based on site visits and correspondence with stakeholders conducted during the summers of 2014 and 2015. All three themes - scale of governance in resource ownership, biocentric conservation values, and anthropocentric utility of the land - are present in each case presented here, and each was chosen to represent a particular theme given that it outweighed the influence of the other themes as a causal mechanism in micro political discourse. The selection of the three cases - in Utah, Arizona, and Wyoming -suffers from bias in support of a particular claim; however my preliminary knowledge of them aided the research design, especially since they populate a spectrum of independent variables useful in making a collective theoretical argument (George and Bennett 2005). Cases are presented in a narrative fashion, a multi-sited ethnographic approach where semi-structured interviews, archival records, and policy analysis are used (Marcus 1995).

\section{Scale of governance: State versus Federal control of natural resources}

In order to utilize the region as a conceptual tool, one must first understand the weight that scale holds as a factor in natural resource governance. Ecological processes are inherently inter-scalar and political-legal systems have emerged at various scales as a way to regulate the contradiction between capital accumulation and degradation of natural processes underpinning the material production of society. But the distribution of these outcomes is often indirect, unjust, or marginalizing which is why conflict persists despite the many forms of governance (Bridge 2000, O'Connor 1988). Stakeholders from community, market, and state groups share knowledge and exhibit power over one another in various ways across the political-legal landscape through co-management, public-private partnerships and private-social partnerships that allow industrial development to produce and displace environmental degradation so that a growth-dependent economy can sustain itself (Lemos and Agrawal 2006). A regional scale perspective on governance regimes provides theoretical utility because it can "emphasize that 'local' politics are shaped by [and shape] broader economic, social, and environmental forces ... [and that] political ecology is most distinctive and powerful when it ascends in explanation from the site of environmental interaction through scales of individuals, households, communities, regions, and states" (Walker and Fortmann 2003). Utah, perhaps more than any other state in the union, embodies the scalar tensions between state and federal agencies that have emerged over the control of public lands, a large part of which has to do with mineral exploration but is underpinned by local land use rights.

Federal lands management regulations, such as the Federal Lands Policy and Management Act that operates as the organic act of the Bureau of Land Management, mediate the multiple uses that at once allow 
local land users and corporate energy producers to accumulate capital and contribute to landscape degradation, albeit in markedly different ways. The Federal Lands Policy and Management Act directs the Bureau of Land Management to conduct inventories and establish resource management plans that take into account, among other things, principles of multiple use and sustained yield. Sustained yield is an interdisciplinary approach to achieve continual economic production through integrated consideration of geologic, biologic, socio-economic, and other sciences that consider present and potential uses. Multiple use management describes the complicated task of balancing land uses that include timber production, cattle ranching, mineral and energy extraction, recreation, watershed sustainability, wildlife and fish populations, and scientific and historical values so that a diversified set of economic activities and environmental process may continue in perpetuity. The Bureau of Land Management allows ranchers to use rangelands for a below market fee in accordance with the carrying capacity of the land, as measured by an animal unit month (a cow and calf). In an ideal scenario this animal unit month rental fee, which is based on the soil type, water resources, number of cattle, and weight of cattle, allows for a sustained yield of the land in perpetuity. Mineral development, however, has the potential to inhibit the sustained yield of multiple use activities.

The General Mining Law of 1872 allows mining to trump multiple use activities as the "...highest and best use of the land." Extractive industries are subject to various federal environmental regulations such as the National Environmental Policy Act, Clean Water Act, and Clean Air Act during the permit and review process. However, oversight and compliance over the course of the energy project's lifespan is often left to state natural resource agencies. For instance, state agencies can apply for and be given preeminence over the Environmental Protection Agency to regulate compliance of water pollution standards, pursuant to the National Pollution Discharge Elimination System. This may be a contributing reason as to why 75 percent of mines fail to meet originally permitted water quality standards in the years after projects are given a green light through the federally mandated environmental assessment process. The contradiction between capital accumulation and ecological degradation is strongly embedded in the extractive sector, where minerals are geologically bound in place but are affected by temporally arcane legal regimes (e.g. the 1872 Mining Law) and through extraction mechanisms that affect inter-scalar environmental processes (e.g. water pollution) (Huber and Emel 2009). Pollution of local watersheds from mine tailings, impacts on basin-wide air quality associated from fossil fuel emissions, and human health risks from carcinogenic releases, are all products of insufficient regulatory oversight, a lack of coordination and government capacity to manage extractive industries (Bodin and Crona 2009, Zimmerer 2011).

In Utah there is a legacy of contested governance between the state and federal government, and the latter owns 70 percent of the land where two-thirds of oil, gas, and coal production activities are located. In 2012 representatives in the Utah legislature introduced H.B. 148, the Transfer of Public Lands Act that would have enabled more petroleum leases. And as another example, the Utah legislature spent US $\$ 10$ million during the 2012 federal government shutdown - more than any other state - to pay to keep its eight national parks open. This move by the state was an attempt to demonstrate it could effectively manage federal lands, however it is unrealistic that this would work beyond the 16-day shutdown because aside from a few highlytrafficked national parks that are a small portion of federal lands in Utah, federal lands require more expenditures and generate less revenue per acre than a typical state trust section, which is in large part due to the de facto mandate of extractive commodity production (e.g. timber, mining, grazing) on smaller, moreeasily managed state lands (Fretwell and Regan 2015). The speculative nature of holding leases on property designated for oil and gas development is important; in 2014 while industry held more than 1.4 million hectares, only 480,000 hectares were in production, indicating that an excess exists beyond the extractive capacity of oil and gas corporations to be profitable in the current market setting (Figure 1, State of Utah 2015). Speculation is a necessary part of the capitalist growth imperative and withholding production in order to hedge bets for a future market, resource recovery innovation, or more flexible regulatory environment is a key feature of extractive energy industries. Production levels have increased at record rates in the state of Utah between the years 2004 and 2014. Oil production nearly tripled from approximately 4 million bbl. to 11 million bbl., and gas production nearly doubled from approximately 1.3 million cubic feet $(37,000$ cubic meters) to 2.5 million cubic feet (72,000 cubic meters) (DOI 2015). According to the Center for Western Priorities, state and federal governments split royalties from the oil and gas industries; the federal government's nation-wide royalty rate is $12.5 \% ; 16.67 \%$ for the state of Utah. These rates are relatively high, 
but arguably neither are high enough to cover the cost of long-term cleanup and potential ecological damage. These revenues represent the largest non-taxable income for the federal government, which is redistributed between infrastructure and social services needed by those living in Utah and other states. These land acquisition efforts are grounded in market speculation and the desire to roll out more flexible environmental regulations, rather than in a need for the state to promote further extraction.

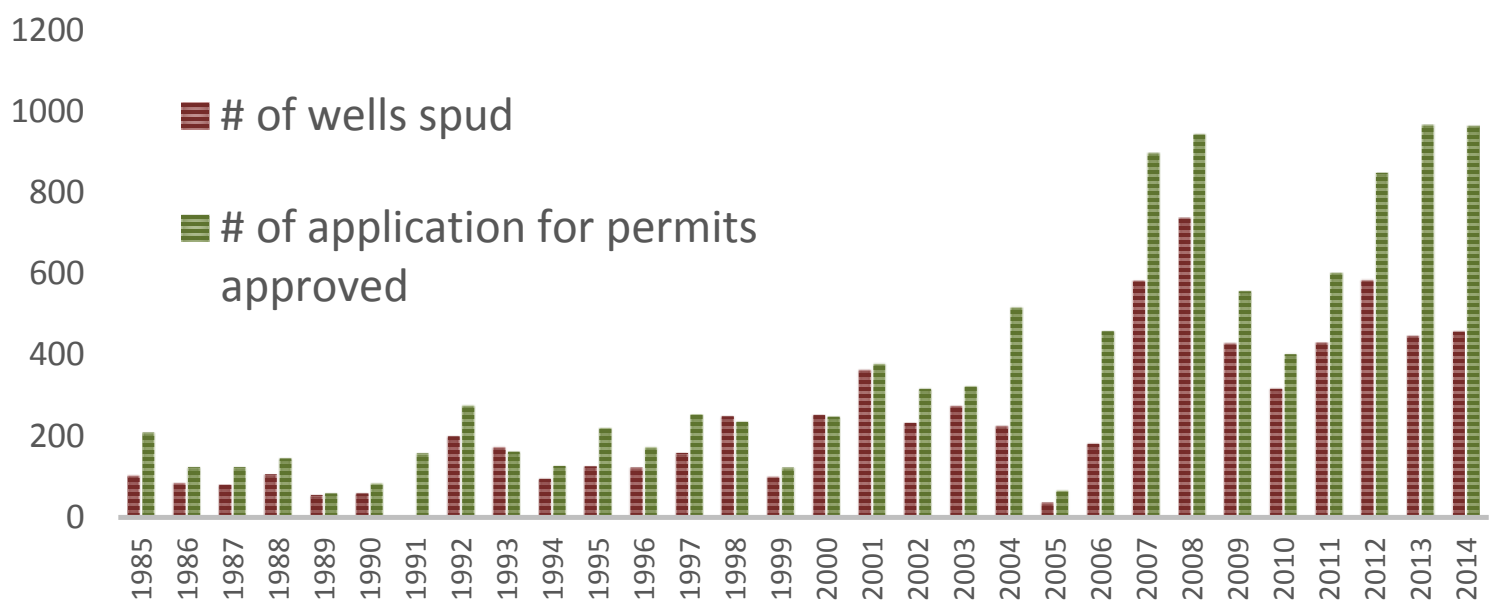

Figure 1: Permits approved versus wells drilled in Utah. Source: Office of Natural Resources Revenue 2015.

The scalar conflict between state and federal government control over lands management for resource extraction or preservation is more of a redux than a new phenomenon. This tension can be traced back to the Sagebrush Rebellion and land privatization theories of the Reagan era, which through Cooperative Management Agreements attempted local scale, private ownership and management "...by selling public land to private individuals in fee simple, [with the theory that] the significant external benefits and costs of public ownership would be internalized, resulting in more efficient production, investment, and distribution [of] decisions." In actuality less oversight of land use and management led to a 'tragedy of the commons', where each user grazed to maximize their economic benefit but collectively, lands became degraded (Zaleha 1986). Likewise, the Wise Use movement was ostensibly about the devolution of environmental governance back to the 'local' scale, but its true goals were and continue to be more anti-state economic control than any type of local land management. In fact, the Wise Use movement of the late 1970s and throughout the 1980s (e.g. the Sagebrush Rebellion) along with the post-recessionary redux today (e.g. rallies about grazing rights in support of Cliven Bundy in southern Nevada and all-terrain vehicle access at Recapture Canyon in Southwest Colorado) are in part a reaction to the iterative and uneven processes of regional restructuring that tie together the political economies of the rural West. These processes include:

- downturns in primary production industries

- rapidly increasing environmental priorities

- significant demographic shifts

- changes in ethnic composition

- and the growth of the hi-tech and service-based sectors (Duane 1998; McCarthy and Guthman 1998; Power 1998). 
The recent Bureau of Land Management grazing case and the all-terrain vehicle rally are reflective of what's going on throughout the greater American West. Whether local land holders have the legal/political/moral right to sell off or lease land for commodity production or amenities is debated. A second question is the pervasiveness of the ecological degradation that will result and whether it can be managed. The supremacy of federal environmental regulations over those of the state in preventing a tragedy of the commons is also debated.

The regional scale of analysis can be useful to assess whether environmental governance outcomes are more effective between stakeholders at the state or federal levels. While the most democratically ideal governance is direct participation and citizen consent, the more practical type of democratic governance is in representative democracy where social regulation is scaled up from more localized moral economies and where elected officials appoint experts to perform the necessary technical oversight to carry out policy (Koontz 1999). A return to John Wesley Powell's idea that watersheds should be used as the geographical basis for governance throughout the Western United States may seem far-fetched in an age of globallyinterconnected resource flows, but it nevertheless can serve as a regionally-connected spatial heuristic to begin thinking about stakeholder conflicts that exist amid resource scarcity. This is in part because such a system has not been embraced.

\section{Biocentric conservation: intrinsic value of nature greater than human need}

A common element in the Western United States is its unparalleled natural setting of mountains, rivers, and deserts. These physical features appear as abundant, age-old, and changeless, with forces on a geologic time scale contributing to their malleability. However, the mines in the mountains, dams on the river, and powerlines crossing the deserts began to increase at a rapid pace during the halcyon days of the 1950s when the region's lengthy roads, industrial agricultural fields, and vast suburbs expanded in step with population growth. This population gained greater access to pristine landscapes via the automobile, and with the help of notable figures like Edward Abbey, David Brower, and Rachel Carson the public became more aware of the environmental degradation resulting from the American way of life. Since the 1980s groups like the Sierra Club have united urban environmentalists across the West with the more radicalized efforts of Earth First! conservationists around issues such as endangered species, diminished water quality, energy development, and climate change. A defining environmental value throughout the American West is biocentric preservationism, seen in the science that supports endangered species listings, the preservation of open space, and the notion that humans are one part of a larger ecological whole, a community that should be put before the narrow economic interests of humans.

Biocentric conservation values have existed for millenia; in the Western tradition they can be traced back from the Greeks to Alexander von Humboldt, and through the genealogy of modern day environmental prophets like Henry David Thoreau, John Muir, and Aldo Leopold (Glacken 1973, Sachs 2007, Worster 1994). However, it was not until the 1980s that they became etched more formally into an academic discipline, conservation biology; the normative conservation ethic would include the promotion of organism diversity, the principle that ecological complexity is good, the ability for evolutionary processes to continue to unfold, and the belief that biological diversity has intrinsic value (Soule 1985). These tenets, and the social construction of nature more broadly, were again debated in the field of environmental politics during the culture wars of the 1990s, which were largely a product of the modernist/post-modernist or structuralist/poststructuralist divide (Cronon 1995, Soulé and Lease 1995). More recently though, this battle as it relates to conservation and resource use or what I shall title the "conservation wars redux" has reentered popular debate, due to an increased focus on big data science, the conservation in-situ of disturbed landscapes, and the valuation of ecosystem services amid increased public recognition of global resource scarcity, biodiversity loss, and climate change (Kareiva and Marvier 2012, Soule 2013). Biocentrists claim their values have been highjacked and compromised by a new conservation ethic that claims to enhance natural systems to benefit the widest number of people, especially the poor, rather than pursuing the protection of biodiversity for biodiversity's sake (Kareiva, Lalasz, and Marvier 2012). Some have contended that the values underlying the debate between biocentric preservation and anthropocentric conservation are altogether similar (Hunter, Redford and Lindenmayer 2014). Although the debate has been an academic one, it has also involved the 
pairing of economic development and conservation initiatives (e.g. Dow Chemical partnering with The Nature Conservancy) versus preservationists who seek to protect vast swaths of land from human development so that ecological and evolutionary processes may be given the chance to unfold (e.g. The Wildlands Network).

In the Santa Rita Mountains of southern Arizona, Rosemont Copper plans to excavate 498 million metric tonnes of ore annually, containing copper, molybdenum, and silver. Rosemont owns 403 hectares that would be used for the mine and processing facility but is seeking 1,485 hectares of mineral leases on the Coronado National Forest, 6 hectares from the Bureau of Land Management and 30 hectares from the state of Arizona, a large part of which would be used for the dumping of waste rock and tailings. This would amount to 1,228 million tons of waste every year over its proposed 20-year operation (USFS 2012). The opposition to this mine has come from people living within the greater Tucson region, county supervisors, environmental coalitions, and even those in federal agencies involved in issuing permits. These stakeholders have advocated that the intrinsic value of nature in the Sky Islands bioregion, including biodiversity and the protection of regional air and groundwater quality, should take precedence over export-driven copper mining. In 2011, a coalition of regional and national environmental groups, led by the Center for Biological Diversity (an NGO) sued the U.S. Forest Service for not allowing public participation as part of the environmental impact statement pursuant with the statutes of the Federal Advisory Committee Act. Indeed, for public land management agencies, information is disseminated through organizational structures that enable the expert knowledge of scientists to be conflated with the power of decision-makers. The performance of an agency is dependent as much on valid science as it is on the mission of an agency, and this is why the U.S. Forest Service has been dubbed the "shining star" of federal lands management agencies, most likely to approve a project as part of its utilitarian mission (Clarke and McCool 1996).

Over the five years prior to 2012 there were three confirmed sightings of jaguar in southeastern Arizona, the only evidence of this species in the United States. The jaguar is listed as federally endangered, however the Sky Islands had not been considered part of their dispersal range. This prompted the U.S. Fish and Wildlife Service to consider listing 339,000 hectares of land as critical habitat for the jaguar and another rare cat, the ocelot, under the Endangered Species Act. In March of 2014 after public comment and agency consideration a reduced area of 309,000 hectares was listed as critical habitat. In his assessment of the proposed mine the Pima County Supervisor cited land management concerns related to landscape genetics and ecological barriers:

This will make it extremely difficult to sustain biodiversity ... because movement of plant and animal individuals and genes across the Rosemont mine and associated infrastructure will be compromised by the land disturbance and associated activities" (Powell and Fonseca 2014).

In May 2014 the Army Corps of Engineers concluded that a mitigation plan by the Rosemont Copper Company, required to comply with a Clean Water Act permit, was inadequate to protect regional water supplies, wildlife habitat, natural springs and wetlands, which led the U.S. Forest Service to extend its review period. This may end the possibility of the mine development altogether. The proposed mine can technically still operate in protected habitat by filing for another Clean Water Act Section 404 permit if mitigatable factors are identified, however it remains to be seen whether these regulatory barriers will make mine development economically prohibitive. The evidence behind biocentric conservation values with this particular case is that the mine's development was halted due to the presence of a charismatic species that was once endemic to the area, was extirpated due to human development, and is now dispersing back into its former range, rather than the potential human and broader environmental impacts due to diminished water quality. The area impacted by the ecological impacts for the landscape-level conservation outcome, promulgated through the Endangered Species Act, stands in contrast to studies showing the spatially smaller ecological impacts of impaired waterways that would result if the mine was developed (Figure 2). That is, the Clean Water Act protects water resources for both people and the environment, and is capable of mitigating the impacts of mineral development across a few hundred kilometers of impaired streams, but the straw that broke the camel's back for the mining corporation ended up being a cross-border immigrant species needing thousands of hectares to roam. 
Efforts to contest extractive development by arguing for the ecological value of the land, and more generally the fight to preserve endangered species, are not new. However, what is clear is that while biocentrists may advocate for the all-out protection of every species everywhere, the species that stop the mine or preserve the landscape are the charismatic megafauna deemed worthy of preservation due to the satisfaction people get for knowing that they are still there. But should conservation efforts only be undertaken if people deem them worthy? In Idaho along the Salmon River, suction dredge mining can take place so long as the water hosting salmon isn't impaired, which is only evident once the mining has displaced the sediment salmon need to spawn, and the populations have already declined. Hard rock mining can take place, so long as species which were extant are no longer there, but if they do appear to recolonize like with the jaguar and ocelot then a project needs to present mitigatable plans. And since a recent decision, oil and gas recovery can now take place unabated in 11 Western states among prairies occupied by Greater sage-grouse, whose noise-sensitive lek (competitive courtship) populations have been in steady decline since cattle grazers settled the region. Interestingly the Lesser prairie-chicken and the Gunnison sage-grouse were listed as threatened at nearly the same time, and it would seem to be a coordinated federal mitigation effort.

\begin{tabular}{|l|l|}
\hline Clean Water Act (people and the environment) & Endangered Species Act (Jaguar) \\
\hline - Lost functions to water upstream of mine & - Jaguars require: vegetative cover, \\
- 41 hectares of corridor, directly or indirectly impacted & $\begin{array}{l}\text { connectivity, and low levels of human activity, } \\
\text { development, and infrastructure }\end{array}$ \\
- Severing surface hydrology and habitat connectivity & - Decreased habitat connectivity due to \\
- Reductions in surface water flow downstream of mine & construction of infrastructure, roads, and fences \\
- 11 hectares of corridor, adverse effects on wetlands & for mining \\
- Groundwater drawdown & - Increased impacts of human activity like noise \\
- Reduced stream flows, 36 riparian areas impaired & - Reduced prey availability \\
- Sensitivity and applicability of groundwater models & - Vegetation removal \\
- All models utilized by USFS show long-term, & - Impacts from mining are proximate to the area \\
significant declines in groundwater quantity/quality & $\begin{array}{l}\text { being developed (<2,000 hectares), while a } \\
\text { jaguar's range is on a landscape level (>200,000 } \\
\text { hectares) }\end{array}$ \\
\hline
\end{tabular}

Figure 2: Blocking mineral development to protect humans or nature? Potential ecological impacts from the proposed Rosemont Copper mine pursuant to the Clean Water Act and the Endangered Species Act. Sources: U.S. Fish and Wildlife Service 2014 and the Environmental Protection Agency 2013.

Society has an a priori assumption that pristine landscapes and their ecological processes existed separate from human occupation at some mythical time, and will continue to exist despite the cognitive dissonance held by many that our landscapes have always been extractive, always modern and malleable to support human use. In the Western United States, a new round of extractive investment in unconventional oil and gas poses an eminent threat to biological diversity because these projects, with their associated roads, wells, and power lines are extensive, rather than intensive like an open pit mine and its infrastructure. Biocentric conservation efforts must continue apace with extractive development throughout the region, but if these efforts are to succeed then a certain amount of cooperation must take place with the local resource users whose livelihoods and land are threatened by extractive development. It is important to recognize that hunters, ranchers, and recreationalists contribute to land degradation in their own right, despite their good intentions: "Hunters, loggers, and developers often express the same love for nature as do professional conservationists, but for many reasons, including economic ones, honorable people may be unable to behave according to their most cherished values, or they honestly disagree on what constitutes ethical behavior" (Soule 1985). 


\section{Anthropocentric resource use: utilizing nature to serve human needs}

Local land owners are upset about the damage to roads that large-haul trucks may cause, and the rumble of Jake brakes ${ }^{2}$ in their otherwise serene rural noisescape. Grazing permittees will no longer be able to access the higher-elevation meadows and springs in summer, needed to meet the increased demand put on their cattle by warmer, drier grazing conditions. Hunters, snowmobilers and off-highway vehicle enthusiasts will now confront a chain link fence across a path they've always used and likely maintained. These situations are faced by anthropocentric conservationists, who in their individual activities contribute to the degradation of the landscape, but equally they adhere to government regulations and follow local norms in order to conserve the land and to sustain their livelihoods or recreational activities. These stakeholders were the most vociferously opposed to a hard rock mine proposed in the Black Hills National Forest (N.F.) in western South Dakota and northeastern Wyoming, not necessarily due to a belief in the intrinsic value of nature for it is own sake, but rather for the recognition that in the short-term a mine would surely curtail access to their public land, and in the long-term probably degrade the roads, water resources, and forest ecology that they rely on collectively. Opposition to the Bearlodge rare earth mine by those engaged in multiple use activities highlights that in the Next West where old and New West land uses and values persist, opposition can come from many angles but perhaps most strongly from those who recognize that their right to utilize surface resources should not be undermined by the 'highest and best use' of the subsurface.

The Black Hills N.F. was the nation's first multiple use landscape; Gifford Pinchot it as his flagship forest to test multiple-use principles when the U.S. Department of Agriculture became responsible for the national forest system in 1905 (Geores 1996). One-fifth of all deer and one-third of all pronghorn (Antilocapra Americana, a unique species resembling an antelope) harvested in Wyoming come from the area surrounding the Bearlodge Mountains - a unit of the Black Hills N.F. - and between 2010 and 2012 there were 161 mountain lions legally hunted within the forest and among surrounding lands (Thompson 2013). In terms of land ownership, the Black Hills N.F. is one of the most fragmented national forests in the country; 101,000 hectares out of the 485,000 hectares are private land, and most of these inholdings were initially acquired through homesteading prior to the National Forest designation and are now used for cattle grazing. Despite being one of the smaller national forests, it is the highest yielding timber producer; in 2009 it produced 112 million board feet (34 million cubic meters) of lumber (USFS 2011). Today, many of the local land users in the National Forest still perceive of the landscape as a "working wilderness." But the level of human intervention, biodiversity loss, and degradation from off-road vehicle use, hunting, fire suppression, and timber production makes this anthropocentrically conserved landscape a far cry from a place "untrammeled by man, where man himself is a visitor" (Brown and Cook 2006, Sayre 2005).

The Bearlodge rare earth mine is proposed for development in the Wyoming portion of the Black Hills N.F. and the mining corporation, Rare Element Resources, is awaiting approval of the final draft environmental impact statement. Mineral development for rare earths will likely take place in the Bearlodge due to the National Forest Management Act and the 1872 Mining Law, which together facilitate hard rock mining as the "highest and best use" of federal lands (Glicksman and Coggins 1997). It is no surprise that many of the citizens who reside in Sundance, the closest city to the proposed project, are in favor of the mine for economic development, and a coalition of environmental groups oppose it due to groundwater impacts and other issues. However, the primary opposition to the mine has come from those engaged in multiple use activities - primarily hunting, off-road vehicle use, and cattle grazing - whose access to the land will be curtailed by the mine, if developed. An analysis of public comments demonstrates that these land users are anthropocentric conservationists because:

- they hold their own economic development above biodiversity

- they believe that nature has never been pristine and so does not need to be restored back to any particular point

- they recognize the resilience of nature even in light of direct human disturbance

- and, they don't believe preservationists are acting in the public interest (Doak et al. 2014).

\footnotetext{
${ }^{2}$ Compression release engine brake.
} 


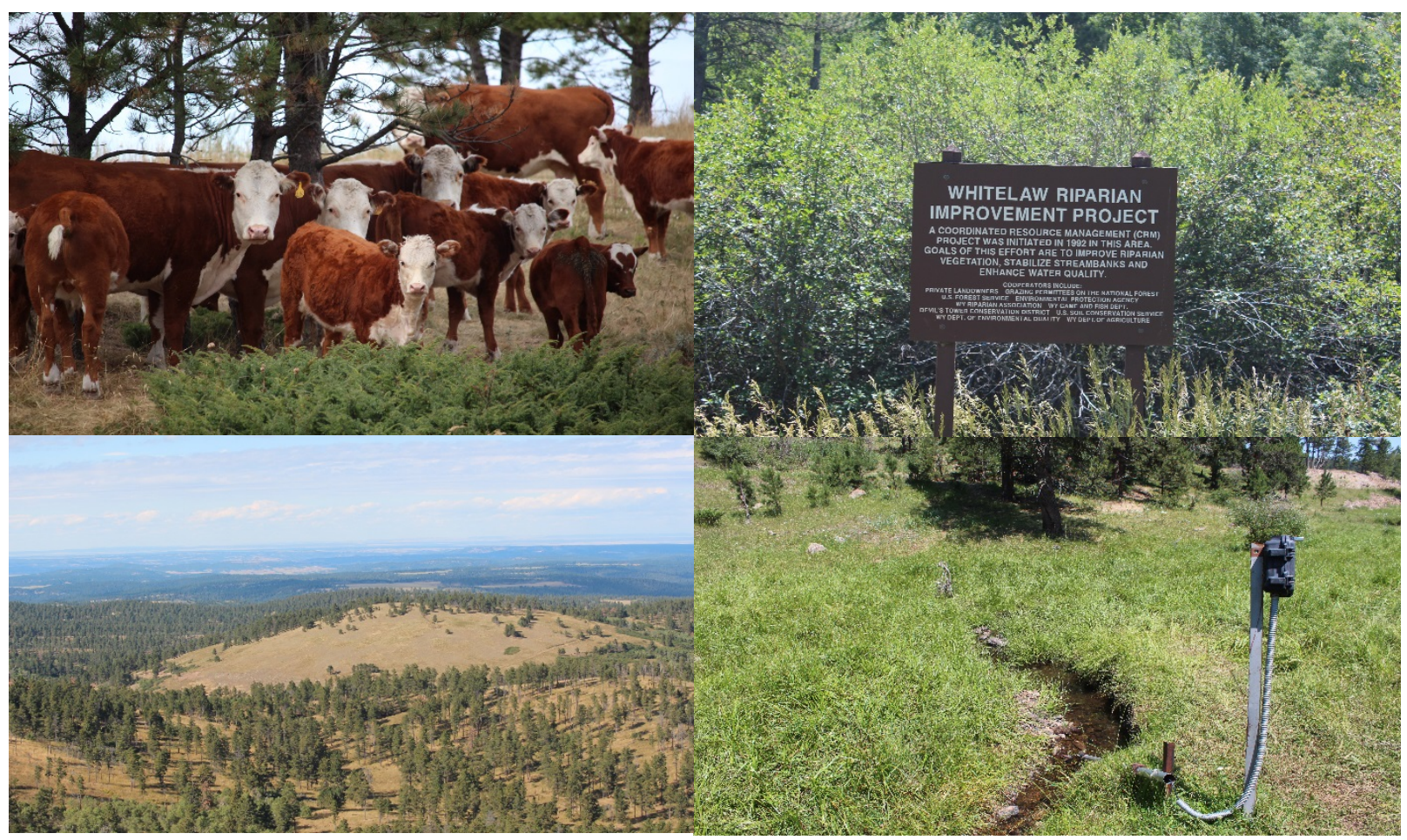

Figure 3: Whitelaw Creek (from upper left, clockwise): Grazing as a cause of degradation; interagency coordinated restoration; monitoring for baseline data on water quality prior to mining; proposed mine site waste tailings location (Whitelaw Creek is on the backside of Bull Hill shown here). Source: author, 2015.

With this in mind, it is important to note that well-known environmentalists throughout history (e.g. Thoreau, Muir, Leopold, etc.) worked land for their own utility while simultaneously advocating for protection of wilderness (Kareiva et al. 2012). It is important to recognize the continued role that anthropocentric resource users will have to play in conserving lands prior to, during, and after extractive development has occurred, especially as coalitions under the banner of formal environmentalism continue to be entangled in a constant cycle of litigation.

Local land users hold the utility of the land for human welfare as sacred, particularly because values associated with labor, recreation, place and identity are tightly woven together in a multiple use patchwork where conservation efforts serve these anthropocentric ideals (Marvier and Kareiva 2014). Whitelaw Creek provides one such example (Figure 3). Historic year-round livestock grazing practices damaged the riparian areas of the tributary and eroded stream banks, which consequently led to increased sediment loading, leading to elevated temperatures that reduced fish stock and invertebrate diversity. The Environmental Protection Agency funded a coordinated restoration effort through Clean Water Act section 319, between the U.S. Forest Service, local land owners, grazing permittees, Wyoming DEQ, and other agencies. The aim was to remedy a tragedy of the commons scenario, and in effect to ensure long-term ecological viability. These efforts centered on stabilizing stream banks, enhancing riparian conditions, and improving water quality through shortduration, multi-pasture grazing, the development of off-channel water sources, and adding cross-fencing to limit pasture access (EPA 2014). Monitoring data from 1992 to 2012 shows that sediment loading was reduced through increased density and diversity of vegetation along stream banks. Ironically, the area where this restoration project was carried out is just downstream from the proposed Bearlodge rare earth mine project and will likely be impacted, despite the previous two decades of restoration. Indeed, hard rock mining is limited in its ability to overcome the second contradiction of capital; extraction degrades the natural 
resources needed to sustain further production of its own material resources, and in the process of doing so it degrades the ecological viability of the land that other users need to sustain their own livelihoods.

This case study and the two preceding ones have highlighted the governance, values, and politicallegal factors underlying extractive industries and associated ecological impacts on federal lands throughout the Western United States. Extractive mineral and fossil fuel development - along with competing land use activities mentioned in this case - take place disproportionately on federal lands due to economic incentives provided by regulation, and historic land tenure regimes. However, it is also important to realize the likelihood that in the future private lands will play a larger role in extractive development as resources become scarcer. For instance, unconventional oil and gas production in recent years has been concentrated on private lands.

\section{Conclusion: conducting research in the Next West, a region in process}

Various themes related to extractive development in the American West have been explored in the preceeding pages, namely the scale of resource control, biocentric preservation values, and the anthropocentric utility of the land. While case studies have been used to highlight a particular theme, it is important to restate that each of these regional cases encompasses elements of each theme. Fossil fuel and mining projects throughout Utah continue to be contested by biocentric and anthropocentric groups such as the Southern Utah Wilderness Alliance, and by grazing permittees who rely on water resources. Bingham Canyon mine just outside Salt Lake City is somewhat of an exception given its increasing proximity to urban areas that are not otherwise suited for wilderness or grazing. Rather, the clash of Old and New West uses of land continues, as suburban tracks are creeping closer to tailings dams built higher and higher to store the toxic byproduct of ramped-up production. Scalar governance issues exist in Arizona, where much of the contested discourse of ecological and hydrogeological impact from proposed mining have been between the state's Department of Mining who has approved state-level environmental permits, and federal agencies including the Environmental Protection Agency, Army of Corps of Engineers, and U.S. Fish and Wildlife Service who have rejected or delayed them. And in the southeastern part of the state - a region impacted by mining and subdivisions for housing - ranchers who are part of the Malpai Borderlands Group continue to advocate for land protection, cooperative management, and restoration efforts that are to a large degree reflective of their own anthropocentric land use ethic. The Black Hills in Wyoming are perhaps best known for their federally managed landmarks - Devils Tower is the nation's first National Monument while Mount Rushmore is arguably the nation's most recognizable geologic feature - however economic impacts of the Clean Power Plan on the Powder River Basin's coal fields and Wyoming's other energy industries dominate a discourse that counterposes state and federal legislation. Conservation projects underpinned by large-scale ecological studies, such as the Wyoming Migration Initiative bring light to the landscape-level impacts of ungulate populations whose routes encounter oil and gas development.

As has been shown here, in order to understand how the politics of ecology and economy are changing throughout the region one must look for similarities as well as differences between sub-regions. While a combination of global markets, federal and state regulations, and community landscape values will continue to drive change, this change will have markedly different outcomes dependent on the local context. This mode of analysis runs the risk of contradiction lest one asks, what are the causal mechanisms that have led scalar politics to dominate in one case, while biocentric conservation has led to an outcome in another, and anthropocentric utility in yet another? Certainly, with regard to broader issues of environmental governance, there are many other themes worthy of addressing through a research design that utilizes case studies. But the theme is somewhat moot compared to the causal mechanism that is driving that theme to persist in one locale and not another.

For the regional political ecologist a mixed methods approach may prove useful in arriving at the causal mechanism. For instance, are there historical land tenure patterns that have led to the present day conflict? One such mechanism could be the Homesteading Act of 1916 which ceded surface rights to private citizens but allowed the federal government to retain subsurface ownership. This Act has led to a patchwork of 'split estates' among private and federal lands. When this policy is paired with the divergent goals of managing the land for habitat connectivity versus mineral development, it can be identified as an historic 
cause of present day land use conflict between market-based energy development, rural economies like grazing, and nature. To test this, a political ecologist using a regional-scale approach could choose case studies whose dependent variables include varying land use outcomes across the same industry, some with known split estates and others without, and through geospatial techniques trace the land tenure of each of these cases backwards and outwards to arrive at a causal mechanism for why a conflict persists 'here' and not 'there'. A mixed methods approach would be bolstered further by social data, for instance conducting surveys of community sentiment for or against a particular project. The regional political ecologist must utilize interdisciplinary methods. Social and natural sciences are both needed to test causal mechanisms.

The Next West will be not be the Old West of commodity-extraction dependent communities, or the New West of amenity-driven communities. It will continue as a hybrid of the two - where macro-level factors such as cheap credit, costly energy, and climate change contribute to local land use conflicts. In the context of extractive development, there will be increasing pressure for the federal government to lease lands for energy development or to delegate authority to the state; increasing pressure for energy development in response to high energy prices (e.g. of oil) or decreasing production costs (e.g. shale gas). There will be increasing opportunity to trade federal lands that are suitable for energy development for private lands that are critical for ecosystem conservation, and increasing pressure for domestic strategic mineral development (e.g. rare earth elements) (Duane 2012). The examples of extractive development in the American West covered in this article, and the Next West scenarios, demonstrate how one region can produce various governance outcomes related to state control over extractive resources and local land access, and the types of values associated with nature in light of resource use, whether biocentric or anthropocentric.

\section{References}

Aschmann, H. 1970. The natural history of a mine. Economic Geography 46(2): 172-189.

BEA. 2014. State personal income. U.S. Bureau of Economic Analysis, Department of Commerce.

Bebbington, A.J. and J. Bury (eds.). 2013. Subterranean struggles: new geographies of extractive industries in Latin America. Austin: University of Texas Press.

Benson, M. 2012. Mining sacred space: law's enactment of competing ontologies in the American West. Environment and Planning A 44(6): 1443-1458.

Blaikie, P.M. and H.C. Brookfield. 1987. Land degradation and society. London: Methuen.

Bodin, Ö. and B.I. Crona. 2009. The role of social networks in natural resource governance: what relational patterns make a difference? Global Environmental Change 19(3): 366-374.

Bridge, G. 2000. The social regulation of resource access and environmental impact: production, nature and contradiction in the US copper industry. Geoforum 31(2): 237-256.

Brown, P.M. and B. Cook. 2006. Early settlement forest structure in Black Hills Ponderosa Pine forests. Forest Ecology and Management 223(1): 284-290.

Clarke, J.N. and D. McCool. 1996. Staking out the terrain: power and performance among natural resource agencies. Albany: SUNY Press.

Cronon, W. 1995. Uncommon ground: toward reinventing nature. New York: Norton.

Doak, D.F., V.J. Bakker, B.E. Goldstein and B. Hale. 2014. What is the future of conservation? Trends in Ecology and Evolution 29(2): 77-81.

DOI. 2015. Reported revenues_-sales volume; sales year; FY2004-FY2013; Federal onshore; Utah. Department of the Interior, Statistical Information.

Duane, T.P. 2012. The Next West. Working Paper. University of California, Santa Cruz.

Duane, T.P. 1998. Shaping the Sierra: nature, culture, and conflict in the changing West. Berkeley: University of California Press.

EPA. 2014. Wyoming: Whitelaw Creek - Coordinated resource management and riparian restoration improvements. Environmental Protection Agency.

Fretwell, H. and S. Regan. 2015. Divided lands: State vs. federal management in the West. PERC Public Lands Report. PERC. 
Geores, M. 1996. Common ground: the struggle for ownership of the Black Hills National Forest. Lanham: Rowman and Littlefield.

George, A.L. and A. Bennett. 2005. Case studies and theory development in the social sciences. Cambridge: MIT Press.

Glacken, C.J. 1973. Traces on the Rhodian shore: nature and culture in Western thought from ancient times to the end of the eighteenth century. Berkeley: University of California Press.

Glicksman, R. L. and G. C. Coggins. 1997. Hardrock minerals, energy minerals, and other resources on the public lands: the evolution of Federal natural resources law. Tulsa Law Review 33: 765-826.

Gulliford, A. 1989. Boomtown blues: Colorado oil shale. University Press of Colorado.

Hostetter, E. 2011. Boomtown landscapes. Material Culture 43: 59-79.

Hunter, M.L., K.H. Redford and D.B. Lindenmayer. 2014. The complementary niches of anthropocentric and biocentric conservationists. Conservation Biology 28(3): 641-645.

Jenkins, J. 2011. The reproduction of the Klamath Basin: struggle for water in a changing landscape. Yearbook of the Association of Pacific Coast Geographers 73(1): 69-78.

Kareiva, P., R. Lalasz and M. Marvier. 2012. Anthropocene revisited. Breakthrough Journal 1(4).

Kareiva, P. and M. Marvier. 2012. What is conservation science? BioScience 62(11): 962-969.

Koontz, T.M. 1999. Citizen participation: conflicting interests in state and national agency policy making. Social Science Journal 36(3): 441-458.

Lemos, M.C. and A. Agrawal. 2006. Environmental governance. Annual Review of Environment and Resources 31(1): 297-325. Researchgate

Marcus, G. 1995. Ethnography of the World System: the emergence of multi-sited ethnography. Annual Review of Anthropology 24: 95-117.

Marvier, M. and P. Kareiva. 2014. The evidence of values underlying 'new conservation'. Trends in Ecology and Evolution 29(3): 131-132.

McCarthy, J. 2002. First World political ecology: lessons from the Wise Use movement. Environment and Planning A 34(7): 1281-1302.

McCarthy, J. and J. Guthman. 1998. Introduction. Special issue: nature and capital in the American West. Antipode 30: 67-72.

Neumann, R. P. 2009a. Political ecology II: theorizing region. Progress in Human Geography: 1-7.

Neumann, R. P. 2009b. Political ecology: theorizing scale. Progress in Human Geography 33(3): 398-406.

O'Connor, J. 1988. Capitalism, nature, socialism: a theoretical introduction. Capitalism Nature Socialism 1: 11-38.

Powell, B. and J. Fonseca. 2014. Impacts of the Rosemont Mine and Management Area 16 on the integrity of the Northern Santa Rita Mountains for wildlife. Pima County Office of Sustainability and Conservation.

Power, T.M. 1998. Lost landscapes and failed economies: the search for a value of place. Washington, D.C.: Island Press.

Robbins, P. 2006. The politics of barstool biology: environmental knowledge and power in greater Northern Yellowstone. Geoforum 37(2): 185-199.

Robbins, P., K. Meehan, H. Gosnell and S. Gilbertz. 2009. Writing the New West: a critical review. Rural Sociology 74(3): 356-382.

Sachs, A. 2007. The Humboldt Current: nineteenth-century exploration and the roots of American environmentalism. London: Penguin.

Sayre, N.F. 2005. Ecological and geographical scale: parallels and potential for integration. Progress in Human Geography 29(3): 276-290.

Schroeder, R.A., K. St. Martin and K.E. Albert. 2006. Political ecology in North America: discovering the Third World within? Geoforum 37(2): 163-168.

Soule, M.E. 1985. What is conservation biology? BioScience 35(11): 727-734. 
Soule, M.E. 2013. The "new conservation". Conservation Biology 27(5): 895-897.

Soulé, M.E. and G. Lease. 1995. Reinventing nature? Responses to postmodern deconstruction. Washington, D.C.: Island Press.

State of Utah. 2015. Permits approved vs. wells drilled in Utah. Division of Oil, Gas, and Mining - Utah Department of Natural Resources.

Thompson, D. 2013. Wyoming Mountain lion mortality report, harvest years: 2010-2012. Wyoming Game and Fish Department.

USFS. 2011. Black Hills National Forest Collaborative Forest Landscape Restoration Project, FY 2011 - FY 2020. United States Forest Service.

USFS. 2012. Draft Environmental Impact Statement for the Rosemont Copper Project. Pima County Arizona. United States Forest Service.

Vayda, A.P. 1983. Progressive contextualization: methods for research in human ecology. Human Ecology 11(3): 265-281.

Vayda, A.P. and B.B. Walters. 1999. Against political ecology. Human Ecology 27(1): 167-179.

Walker, P.A. and L. Fortmann. 2003. Whose landscape? A political ecology of the 'exurban' Sierra. Cultural Geographies 10(4): 469-491.

Worster, D. 1994. Nature's economy: a history of ecological ideas. Cambridge: Cambridge University Press.

Zaleha, D.B. 1986. The rise and fall of BLM's cooperative management agreements: a livestock management tool succumbs to judicial scrutiny. Environmental Law 17: 125-

Zimmerer, K.S. 2011. New geographies of energy: introduction to the special issue. Annals of the Association of American Geographers 101(4): 705-711. 